\title{
The Relationship Between Hematological Malignancy and Lipid Profile
}

\author{
Hematolojik Malignite ve Lipid Profili Arasındaki İlişki
}

\section{Erman OZTURK ๑}

Ethics Committee Approval: This study was approved by İstanbul Medeniyet University Ethics Committee, 13 January 2021, 2020/0759.

Conflict of interest: The authors declare that they have no conflict of interest.

Funding: None.

Informed Consent: Not Applicable.
Cite as: Ozturk E. The relationship between hematological malignancy and lipid profile. Medeni Med J. 2021:36:146-51.

\begin{abstract}
Objective: Hypocholesterolemia is a metabolism disorder that may be seen in chronic diseases and malignancies. Various dyslipidemia profiles have been shown in adult and pediatric hematological malignancies. We aimed to evaluate the lipid profile properties in patients diagnosed with a hematological malignancy compared to a healthy control group.

Method: Out of 1213 patients diagnosed with hematologic malignancy, the data of 98 patients whose pretreatment lipid profiles had already been studied, were reviewed. Forty healthy individuals were selected as the control group. The levels of total cholesterol, triglycerides (TG), low-density lipoprotein ( $L D L)$, and high-density lipoprotein $(H D L)$ were compared.

Results: Triglyceride values were significantly higher $(p=0.02)$, and the total cholesterol, $L D L$ and $H D L$ levels were lower in the study group compared to the control group. Triglyceride values were higher $(p=0.013)$, and $H D L$ levels were lower $(p=0.022)$ in parallel with increases in uric acid levels. There was a significant correlation between the International Prognostic Index (IPI) score and TG $(p=0.003)$ in those diagnosed with non-Hodgkin lymphoma (NHL). Whereas no significant correlation was found between TG, total cholesterol, and LDL values in the limited (early) and advanced stage NHL, while a significant negative correlation was found with HDL $(p=0.027)$.

Conclusion: Hypertriglyceridemia, as well as low $L D L$ and $H D L$ values may be seen in hematological malignancies. It should be kept in mind that there may be chronic diseases and malignancies in the etiology of incidental hypocholesterolemia and hypertriglyceridemia. Further studies are needed on this subject to determine the effects of dyslipidemia on the pathogenesis and prognosis of the disease in hematological malignancies.
\end{abstract}

Keywords: Hematological neoplasm, dyslipidemia, hypertriglyceridemia

öz

Amaç: Hipokolesterolemi kronik hastalıklar ve malignitelerde görülebilen bir lipid metabolizma bozukluğudur. Erişkin ve çocuk hematolojik malignitelerinde değişik dislipidemi profilleri gösterilmiştir. Bu çalışmada hematolojik malignite tanısı olan hastalarda sağlıklı kontrol grubuna göre lipid profilinin özelliklerini değerlendirilmesi amaçlandı.

Yöntem: Hematolojik malignite tanısı almış 1213 hasta içerisinden tedavi öncesi lipid profili bakılmış 98 hastanın verileri geriye dönük tarandı. Kontrol grubu olarak 40 sağlıkı birey alındı. Hasta ve kontrol grubunda total kolesterol, trigliserid (TG), düşük yoğunluklu lipoprotein (LDL) ve yüksek yoğunluklu lipoprotein (HDL) düzeyleri karşılaştırıldı.

Bulgular: Hematolojik maligniteli hastalarda kontrol grubuna göre TG düzeyleri daha yüksek $(p=0.02)$ saptanırken, total kolesterol, $L D L$ ve $H D L$ daha düşük saptandı. Ürik asit düzeyi artısına paralel olarak, TG düzeyinin yüksek ( $p=0.013), H D L$ düzeylerinin ise düşük $(p=0.022)$ olduğu görüldü. Hodgkin dışı lenfoma tanısı olanlarda Internasyonel Prognostik İndex (IPI) skoru ile TG düzeyleri arasında ilişki saptandı $(p=0.003)$. Sınırlı ve ileri evre lenfomalarda TG, total kolesterol ve $L D L$ değerleri arasında ilişki saptanmaz iken, $H D L$ arasında negatif korelasyon gösterildi $(p=0.027)$.

Sonuç: Hematolojik malignitelerde hipertrigliseridemi, $L D L$ ve HDL düşüklüğü olabileceği görülmektedir. Insidental saptanan hipokolesterolemi ve hipertrigliseridemi etyolojisinde kronik hastalık ve malinitelerin olabileceği değerlendirilmelidir. Dislipideminin hastalık patogenezi ve prognozunda etkisinin belirlenmesi için bu konuda çalışmalara ihtiyaç vardır.

Anahtar kelimeler: Hematolojik neoplazm, dislipidemi, hipertrigliseridemi
Received: 27 March 2021

Accepted: 29 May 2021

Online First: 18 June 2021

Corresponding Author: E. Ozturk

ORCID: 0000-0002-1559-8047 Istanbul Medeniyet University Faculty of Medicine, Department of Hematology, Istanbul, Turkey

erman.ozturk@medeniyet.edu.tr 


\section{INTRODUCTION}

Hypocholesterolemia may be seen in patients with hematological malignancy, as well as anemia, hyperthyroidism, adrenal insufficiency, and liver failure ${ }^{1}$. De novo produced fatty acids are thought to be used in the membrane production, energy supply and proliferation of cancer cells ${ }^{2,3}$. The need for lipids against apoptosis increases in neoplasms that do not proliferate rapidly ${ }^{4}$. While endogenous lipogenesis is considered as the main source for fatty acids in cancer cells, recent evidence indicates that they obtain fatty acids through lypolysis ${ }^{2,5}$. Lipoprotein lipase is not found in healthy lymphocytes, while cancer cells were found to cause dyslipidemia by introducing greater number of lipoproteins into cells in patients with chronic lymphocytic leukemia $(C L L)^{6}$. Dyslipidemia may manifest itself with hypertriglyceridemia, lower levels of low-density lipoprotein (LDL) and high-density lipoprotein (HDL). It was shown that existing dyslipidemia can also be evaluated as an indicator of treatment response ${ }^{7}$. In this study, we aimed to evaluate the lipid profile in patients diagnosed with hematological malignancy compared to the healthy control group.

\section{MATERIAL and METHODS}

A total of 1213 patients aged over 18 years who presented to the hematology clinic between 2015 and 2021 received the diagnosis of a hematological malignancy. Only patients who did not receive chemotherapy were screened retrospectively. Out of 1213 patients with malignancy diagnosis, 98 with pre-treatment lipid profiles already studied were evaluated. People whose lipid profiles were examined in routine health check-ups; who did not use antilipidemic drugs or were not diagnosed with cancer, renal failure or chronic liver disease were determined as the control group. Biochemical tests studied in the morning, following fasting for 6 to 10 hours at night, were evaluated. The study was approved by the local ethics committee (2020/0759) and conducted in accordance with the the Principles of Helsinki Declaration.

\section{Statistical Analysis}

Descriptive values of the variables were expressed as mean $\pm \mathrm{SD}$ and frequencies. Using the Kolmogorov-Smirnov test, the normality of the variables was analyzed. Age, LDH, total cholesterol, HDL, LDL, and uric acid values were all normally distributed. An independent sample t-test was used to evaluate the differences between the patient group with hematological malignancy and the control group. The correlations between lipid profiles and patients' diagnoses and other biochemical test results were assessed with Spearman's rank and Pearson's correlation analyses, respectively. All statistical analyses were performed using SPSS (Statistical Package for the Social Sciences) software. The results were evaluated at $95 \%$ confidence interval, and $\mathrm{p}<0.05$ values were considered statistically significant.

\section{RESULTS}

A total of 138 persons including 98 patients, and

Table 1. General features of the patients.

\begin{tabular}{llll}
\hline & Patient (n:98) & Control (n:40) & p \\
\hline $\begin{array}{l}\text { Age (years), } \\
\text { mean (SD) }\end{array}$ & $56(17)$ & $54(13)$ & 0.438 \\
$\begin{array}{l}\text { Female (\%) } \\
\text { Male (\%) }\end{array}$ & $39(40)$ & $21(52.5)$ & 0.178 \\
Diagnosis & $59(60)$ & $19(47.5)$ & \\
NHL & $48(49 \%)$ & & \\
HL & $3(3 \%)$ & & \\
AML & $26(27 \%)$ & & \\
ALL & $14(14 \%)$ & & 0.02 \\
MDS & $5(5 \%)$ & & \\
CLL & $2(2 \%)$ & & \\
Triglyceride & $179.5(55-573)$ & $145.8(41-312)$ & \\
(mg/dl) & & & \\
Total Cholesterol & $153(67-284)$ & $196.7(116-304)$ & $<0.001$ \\
(mg/dl) & & & $<0.001$ \\
LDL (mg/dl) & $89(15-214)$ & $118.5(66-224)$ & $<001$ \\
HDL (mg/dl) & $29(5-71)$ & $49(27-95)$ & $<0.001$ \\
Uric Acid (mg/dl) & $6.1(1.9-13.7)$ & & \\
\hline
\end{tabular}

NHL, Non-Hodgkin lymphoma; HL, Hodgkin lymphoma; $A M L$, Acute myeloid leukemia; ALL, Acute lymphoblastic leukemia; MDS, Myelodysplastic syndrome; CLL, Chronic lymphocytic leukemia; HDL, high-density lipoprotein; LDL, low-density lipoprotein. 


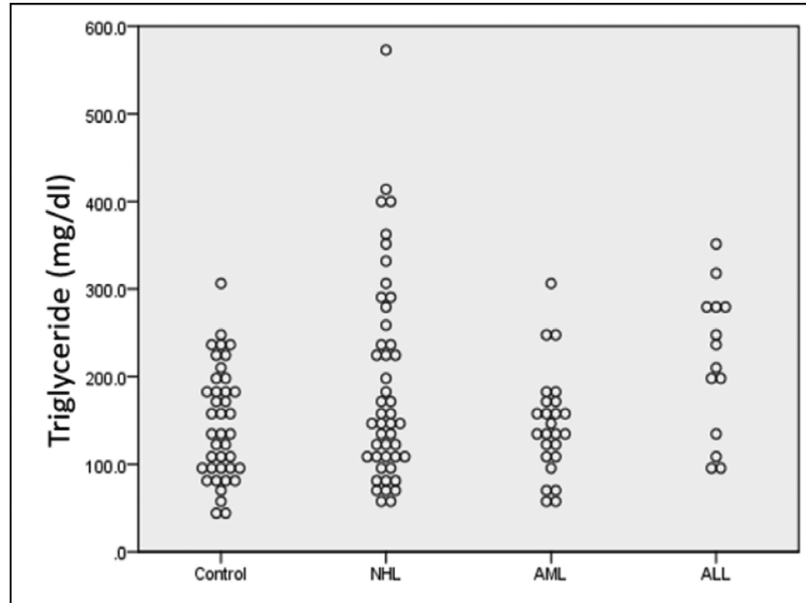

A

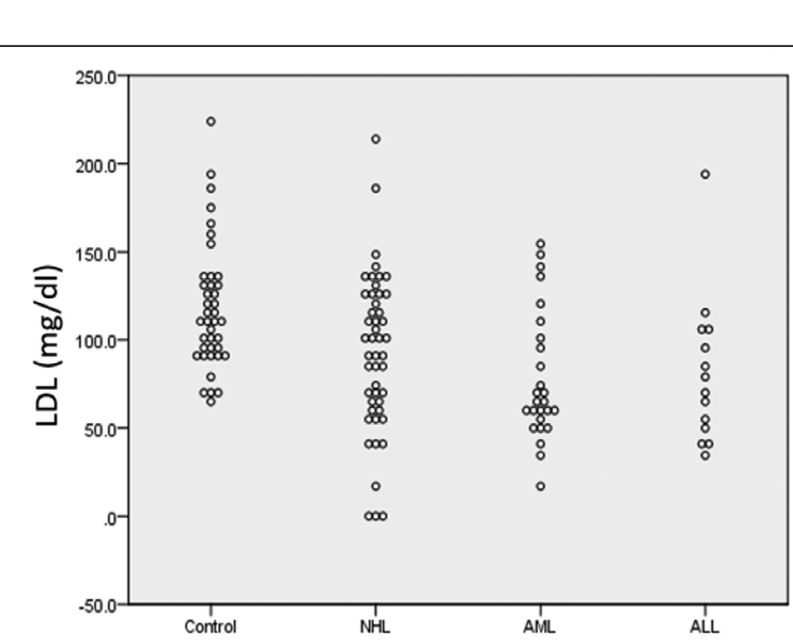

C

A. Control vs NHL $(p=0.025)$, Control vs AML $(p=0.9)$, Control vs ALL $(p=0.02)$; B. Control vs NHL ( $p<0.001)$, Control vs AML ( $p<0.001)$, Control vs ALL ( $p<0.001)$; C. Control vs NHL $(p=0.004)$, Control vs AML ( $<<0.001)$, Control vs ALL $(p=0.002)$; D. Control vs NHL $(p<0.001)$, Control vs AML $(p<0.001)$, Control vs ALL $(p<0.001)$.

ALL Acute lymphoblastic leukemia; AML, acute myeloid leukemia; HDL, high density lipoprotein; LDL, low density lipoprotein; NHL, NonHodgkin lymphoma.

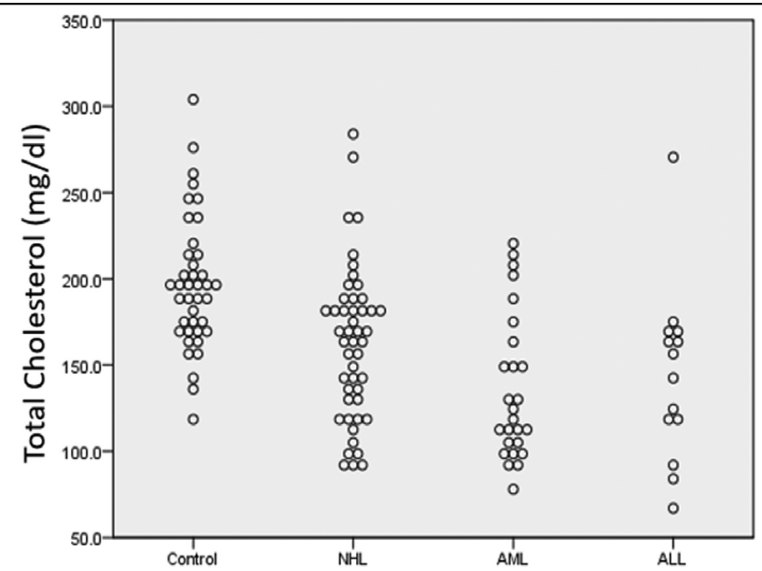

B

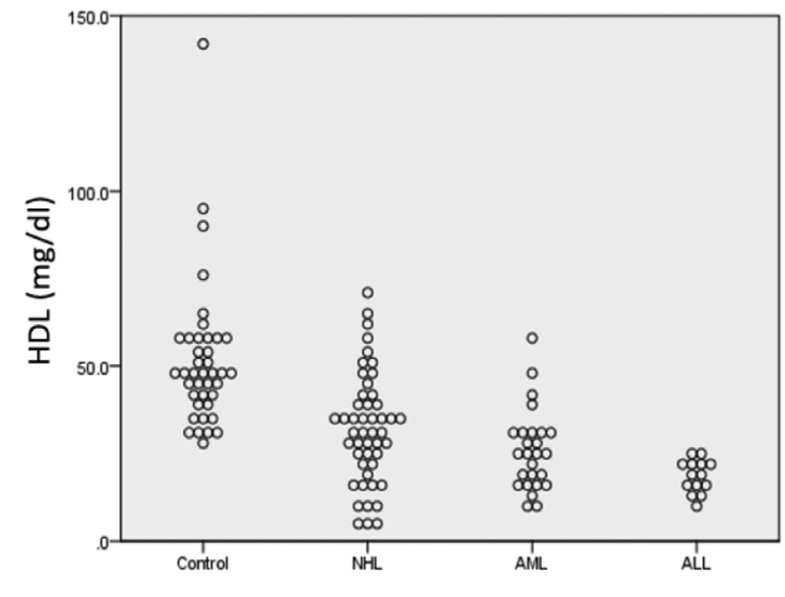

D

Figure 1. Evaluation of lipid profile including triglycerides, total cholesterol, HDL, and LDL between the patient and control groups.

40 control subjects were included in the study. The median ages of the patient, and the control group were 56 , and 54 years, respectively. No significant difference was found between the patient and control groups in terms of age and gender distribution. Demographic features of the patients are summarized in Table 1 . In the hematological 
(Table 1$)$. In the study group higher TG ( $\mathrm{r}(93)$ $=.257, \mathrm{p}=0.013$ ), and lower HDL ( $\mathrm{r}(95)=.236$, $\mathrm{p}=0.022$ ) values were detected in parallel with increasing uric acid levels, but there was no such relationship between $\mathrm{LDL}$ and total cholesterol levels ( $p=0.289$ and $p=0.508$, respectively). When the subgroups were evaluated, it was found that non-Hodgkin lymphoma (NHL), acute myeloid leukemia (AML), acute lymphoblastic leukemia (ALL) patients had lower levels of HDL, LDL, and total cholesterol compared to the control group. TG values were higher in all patient subgroups, except for AML, compared to the controls (Figure $1)$. In the subgroup analysis, TG values were higher $(p=0.026)$, and total cholesterol levels were lower $(p=0.013)$ in the NHL group compared to the AML patients. No significant difference was observed among the AML and NHL subgroups in terms of LDL and HDL values $(p=0.18$ and $p=0.08$, respectively). Results of the Spearman's correlation analysis performed in patients diagnosed with lymphoma indicated the presence of a statistically significant correlation between the IPI scores and TG ( $r s(31)=.516, p=0.003$ ) but lack of any statistically significant correlation between IPI scores, and total cholesterol, LDL and HDL values $(p=0.36, p=0.08$, and $p=0.24$, respectively). There was a statistically significant negative correlation among limited (Stages I-II) / advanced stage (Stages III-IV) NHLs and HDL values (rs (30) $=-.404, p=0.027$ ), but without any significant correlation with other lipid parameters. No significant correlation was found between the Ki-67 values and the lipid profile in patients diagnosed with lymphoma. Results of the Pearson's correlation analysis indicated the presence of a significant positive correlation between LDH and TG values ( $r(47)=.356$, $\mathrm{p}=0.014)$ and significant negative correlation between LDH and LDL values ( $r(48)=-.332$, $\mathrm{p}=0.021$ ).

\section{DISCUSSION}

Previous studies stated that dyslipidemia may present in malignancies ${ }^{1,8}$. However, these findings were based on metabolic data and comorbidity variables. In some studies, comparisons were made with control groups by excluding all factors that may cause hyperlipidemia?. It is thought that the present research better reflects normal population data because every relevant factor was included in the analysis, except for the use of antilipidemic drugs. In our study, significantly higher TG values and lower total cholesterol, LDL, and HDL values were found in the patients with hematological malignancy compared to the control group.

In the subgroup evaluations, no significant difference was found between the AML patients and the control group in terms of TG values $(p=0.09)$. This finding was consistent with the data in AML patients reported by Usman et al. ${ }^{9}$. A significant increase was found in TG values in NHL and ALL patients compared to the control group in consistent with relevant literature data ${ }^{10}$. Although Janus et al. ${ }^{1}$ reported higher TG values in acute leukemia, the subgroup discrimination between AML and ALL was not specified, and the TG profile in AML patients has not been well understood. Very recently Sun et al. ${ }^{11}$ analyzed acute promyelocytic leukemia (APL) and nonAPL AML patients and found that only $28.4 \%$ of non-APL AML patients had hypertriglyceridemia and the mean triglyceride value was $139 \mathrm{mg} / \mathrm{dl}$. Triglyceride values were higher in APL patients and although the reason is not known yet, the authors speculated that this may be related to the presence of a PML/RAR $\alpha$ fusion protein, and the induction of abnormal lipid metabolism in APL patients by ATRA therapy ${ }^{11}$. It is well known that ATRA is an active metabolite of vitamin A and can cause hypertriglyceridemia. Triglyceride level in APL also increased during induction treatment with all-trans retinoic acid (ATRA) $)^{11,12}$. Dyslipidemia has also been shown in chronic lymphocytic leukemia, and it was found that total cholesterol, LDL, and HDL values decreased, but TG values did not change with advanced stages 
of CLL patients ${ }^{10}$. Similar findings were shown in this study in NHL patients with limited or advanced stages of the disease. However, a direct and compatible correlation could not be shown between Ki-67, which is one of the indicators of cell cycle rate, and dyslipidemia. These findings suggested a relationship between dyslipidemia and disease burden, but dyslipidemia may not be directly correlated with mitotic activity in lymphoma. In this study, hypocholesterolemia was more prevalent, and TG values were higher in ALL patients than in the control group. While LDL values were relatively lower in this patient group, higher TG and LDL levels have been reported in literature of the pediatric age group ${ }^{13}$. Lipoprotein lipase (LPL), which hydrolyzes triglycerides, is the major plasma lipolytic enzyme ${ }^{14}$. Fasting hypertriglyceridemia may be observed with LPL deficiency ${ }^{15,16}$. In lymphoproliferative disorders, antibodies may increase clearance of factors required for LPL activity or may disrupt LPL activity ${ }^{17,18}$. When the AML and NHL subgroups were compared, TG was higher $(p=0.026)$, and total cholesterol was lower $(p=0.013)$ in $\mathrm{NHL}$ patients. No significant difference was found in terms of LDL and HDL $(p=0.18$ and $p=0.08$, respectively), suggesting that TG values were higher in lymphoproliferative neoplasms rather than myeloid malignancies. This may be due to the presence of lipoprotein lipase enzyme in the hematopoietic stem cells and the increased expression of this enzyme in AML; but so far, this enzyme has not been studied in $A M L^{19}$. When the most affected lipid parameters were examined in all groups, lower HDL and higher TG values were observed (Figure 1). This finding was attributed to the fact that the TG was predominantly higher in lymphoid neoplasms, which was the most frequent diagnosis in this patient group.

The limitations of this study are retrospective evaluation of the data, the inhomogeneity of the patients, and failure to monitor lipid profiles once the treatment response was achieved. Although patients not being homogenous on a single diagnosis can be considered a limitation, the demonstration of dyslipidemia in all hematological malignancies is a strength of this study.

Hypocholesterolemia is not a common pathology in the general population and may be seen due to malnutrition and increased erythropoietic activity in cases of chronic anemia other than familial genetic pathologies ${ }^{20}$. Detection of unexpected hypertriglyceridemia with hypocholesterolemia may bring into question the above-mentioned pathologies and, in the absence of these pathologies, the possibility of chronic disease or malignancy should be investigated. It was stated that dyslipidemia can be used as a prognostic marker in some hematological neoplasms ${ }^{21}$. Therefore, it may be necessary to determine different cut-off values for triglyceride, total cholesterol, LDL, and HDL so as to use them as diagnostic or prognostic markers in patients with a malignancy.

\section{CONCLUSION}

Hypertriglyceridemia, low LDL and HDL values may be seen in hematological malignancies. Further prospective and comprehensive studies are needed to determine the effects of dyslipidemia on the pathogenesis and prognosis of the disease in hematological malignancies.

\section{REFERENCES}

1. Kuliszkiewicz-Janus $M$, Małecki R, Mohamed AS. Lipid changes occuring in the course of hematological cancers. Cell Mol Biol Lett. 2008;13:465-74. [CrossRef]

2. Menendez JA, Lupu R. Fatty acid synthase and the lipogenic phenotype in cancer pathogenesis. Nat Rev Cancer. 2007;7:763-77. [CrossRef]

3. Kuemmerle NB, Rysman E, Lombardo PS, et al. Lipoprotein lipase links dietary fat to solid tumor cell proliferation. Mol Cancer Ther. 2011;10:427-36. [CrossRef]

4. Rysman E, Brusselmans K, Scheys K, et al. De novo lipogenesis protects cancer cells from free radicals and chemotherapeutics by promoting membrane lipid saturation. Cancer Res. 2010;70:8117-26. [CrossRef]

5. Zaidi N, Lupien L, Kuemmerle NB, Kinlaw WB, Swinnen JV, Smans K. Lipogenesis and lipolysis: The pathways exploited by the cancer cells to acquire fatty acids. Prog Lipid Res. 2013;52:585-9. [CrossRef] 
6. Heintel D, Kienle D, Shehata M, et al. High expression of lipoprotein lipase in poor risk B-cell chronic lymphocytic leukemia. Leukemia. 2005;19:1216-23. [CrossRef]

7. Halton JM, Nazir DJ, McQueen MJ, Barr RD. Blood lipid profiles in children with acute lymphoblastic leukemia. Cancer. 1998;83:379-84. PMID: 9669823

8. Mulas MF, Abete C, Pulisci D, et al. Cholesterol esters as growth regulators of lymphocytic leukaemia cells. Cell Prolif. 2011;44:360-71. [CrossRef]

9. Usman H, Rashid R, Ameer F, et al. Revisiting the dyslipidemia associated with acute leukemia. Clin Chim Acta. 2015;444:43-9. [CrossRef]

10. Yavasoglu I, Sargin G, Yilmaz F, et al. Cholesterol levels in patients with chronic lymphocytic leukemia. J Natl Med Assoc. 2017;109:23-7. [CrossRef]

11. Sun J, Lou Y, Zhu J, et al. Hypertriglyceridemia in newly diagnosed acute promyelocytic leukemia. Front Oncol. 2020;10:577796. [CrossRef]

12. Staels, B. Regulation of lipid and lipoprotein metabolism by retinoids. J Am Acad Dermatol. 2001;45:S158-67. [CrossRef]

13. Morel S, Leahy J, Fournier M, et al. Lipid and lipoprotein abnormalities in acute lymphoblastic leukemia survivors. J Lipid Res. 2017;58:982-93. [CrossRef]

14. Fielding BA, Frayn KN. Lipoprotein lipase and the disposition of dietary fatty acids. Br J Nutr. 1998;80:495502. [CrossRef]

15. Babirak SP, Iverius PH, Fujimoto WY, Brunzell JD. Detection and characterization of the heterozygote state for lipoprotein lipase deficiency. Arteriosclerosis. 1989;9:326-34. [CrossRef]

16. Miesenböck G, Hölzl B, Föger B, et al. Heterozygous lipoprotein lipase deficiency due to a missense mutation as the cause of impaired triglyceride tolerance with multiple lipoprotein abnormalities. J Clin Invest. 1993;91:448-55. [CrossRef]

17. Beaumont JL, Berard $M$, Antonucci $M$, Delplanque B, Vranckx R. Inhibition of lipoprotein lipase activity by a monoclonal immunoglobulin in autoimmune hyperlipidemia. Atherosclerosis. 1977;26:67-77. [CrossRef]

18. Nozaki S, Ito Y, Nakagawa T, Yamashita S, Sasaki J, Matsuzawa Y. Autoimmune hyperlipidemia with inhibitory monoclonal antibodies against low density lipoprotein binding to fibroblasts in a case with multiple myeloma. Intern Med. 1997;36:920-5. [CrossRef]

19. Liu C, Han T, Stachura DL, et al. Lipoprotein lipase regulates hematopoietic stem progenitor cell maintenance through DHA supply. Nat Commun. 2018;9:1310. [CrossRef]

20. Shalev H, Kapelushnik J, Moser A, Knobler H, Tamary H. Hypocholesterolemia in chronic anemias with increased erythropoietic activity. Am J Hematol. 2007;82:199-202. [CrossRef]

21. Tefferi A, Nicolosi M, Penna D, et al. Development of a prognostically relevant cachexia index in primary myelofibrosis using serum albumin and cholesterol levels. Blood Adv. 2018;2:1980-4. [CrossRef] 